\title{
Cyanobacteria species dominance and diversity in three Australian drinking water reservoirs
}

\author{
Benny Zuse Rousso $\cdot$ Edoardo Bertone $\mathbb{D} \cdot$ Rodney A. Stewart $\cdot$ Sara P. Hughes $•$ \\ Peter Hobson • David P. Hamilton
}

Received: 3 September 2021/Revised: 5 December 2021/Accepted: 24 December 2021/Published online: 28 January 2022

(C) The Author(s) 2022

\begin{abstract}
The objective of this study was to identify correlations between environmental variables and cyanobacterial diversity, succession and dominance in three Australian water supply reservoirs. We assessed up to 15 years of in-lake water quality monitoring data from Lake Wivenhoe and Lake Tingalpa (Queensland), and Lake Myponga (South Australia). Lakes Wivenhoe and Tingalpa, subject to a subtropical climate, had higher cyanobacterial richness than Lake Myponga in temperate South Australia. Richness in the subtropical lakes was positively correlated $(P<0.05)$ with total cyanobacteria biomass, and cyanobacteria biovolume $>0.03 \mathrm{~mm}^{3} / 1$ (Alert level 1; World Health Organization) was often composed of multiple cyanobacteria species. Peaks in
\end{abstract}

Handling editor: Judit Padisák

Supplementary Information The online version contains supplementary material available at https://doi.org/10.1007/ s10750-021-04794-5.

B. Z. Rousso · E. Bertone $(\square) \cdot$ R. A. Stewart

Griffith School of Engineering and Built Environment, Griffith University, Parklands Drive, Southport,

QLD 4222, Australia

e-mail: e.bertone@griffith.edu.au

B. Z. Rousso - E. Bertone - R. A. Stewart

Cities Research Institute, Griffith University, Parklands

Drive, Southport, QLD 4222, Australia total cyanobacteria biomass and diversity occurred in all three lakes from late spring to early autumn. Unicellular picocyanobacterial dominance was negatively correlated $(P<0.05)$ with total nitrogen while dominance of colonial and filamentous species with larger cells (e.g. Microcystis spp., Raphidiopsis spp., Dolichospermum circinale) was positively correlated $(P<0.05)$ with total phosphorus. Among the species with larger cells, diazotrophic $D$. circinale often dominated when total nitrogen was at low concentrations. Our results support decision making for selecting cyanoHAB control strategies based on single- or multi-species dominance and reinforce that new monitoring technologies could support species-level assessments.

Keywords CyanoHAB - Phytoplankton succession · Diversity $\cdot$ Water resources management

\author{
B. Z. Rousso - E. Bertone - D. P. Hamilton \\ Australian Rivers Institute, Griffith University, 170 \\ Kessels Road, Nathan, QLD 4111, Australia \\ S. P. Hughes \\ South-East Queensland Water (Seqwater), Gold Coast, \\ Australia \\ P. Hobson \\ South Australia Water (SA Water), Adelaide, Australia
}




\section{Introduction}

Phytoplankton regulate many ecological processes in waterbodies, and understanding their dynamics is, therefore, essential to optimize water resources management and support aquatic ecosystem health (Willén, 2000). Eutrophication modifies phytoplankton community structure, which can potentially lead to harmful algal blooms, often dominated by cyanobacteria (cyanoHABs). CyanoHABs impact the ecology and economics of water resources, and human health, especially when associated with production of cyanotoxins (Metcalf \& Codd, 2012) and taste and odour compounds (Watson et al., 2016). Their ecological impacts include changes in community structure, trophic cascades and biogeochemical cycles of waterbodies (Sukenik et al., 2015).

Cyanobacteria are ancient microorganisms adapted to a wide range of environmental conditions. Variations in cyanobacteria morphology (e.g. cell size and colony formation, Whitton \& Potts, 2007; Xiao et al., 2018), gas vesicles for floatation (Pfeifer, 2012), metabolic processes (e.g. diazotrophy, Bryant, 2006) and toxin production (Catherine et al., 2013) support adaptation to a wide range of habitats and are associated with the cosmopolitan distribution of cyanobacteria. Species-specific traits interact in complex ways with environmental conditions that influence the timing and magnitude of cyanoHABs. Understanding cyanobacterial succession and dominance can improve water resources management by controlling environmental drivers that may otherwise stimulate cyanoHABs species (Dokulil \& Teubner, 2000). Current scientific understanding of cyanoHABs derives mostly from field observations of cyanobacteria succession or laboratory experiments focused on their physiology.

Laboratory experiments have been used to isolate the factors that affect cyanobacteria growth, but they do not simulate synergistic or antagonistic responses to multiple variables that cannot be replicated in vitro (Reynolds \& Irish, 1997). Field studies of changes in abundance or biomass of species through time at a particular location are commonly used to understand cyanobacteria community adaptation to changes in environmental conditions and to test hypotheses related to cyanobacteria ecology (Ludwig et al., 1988).

Shifts to cyanobacterial dominance in phytoplankton communities, commonly associated with
cyanoHABs, have been observed in lakes in different climatic zones and regions of the world (see (NiamienEbrottie et al., 2015). Increases in eutrophication and temperature are widely accepted as favouring cyanobacteria dominance over other phytoplankton groups (Dokulil \& Teubner, 2000). However, the high diversity of cyanobacteria and the wide variety of adaptive traits among species, strains and ecotypes (Mur et al., 1993; Ye et al. 2019) result in many other abiotic factors contributing to shifts in cyanobacterial species dominance. For instance, thermal stratification and mixing patterns (Paerl \& Huisman, 2009), water transparency (Vanderley et al., 2021), nitrogen to phosphorus ratios (Zhang \& Rao, 2012), chemical oxidation state of inorganic nutrients (Amorim et al., 2020; Zhang et al., 2021), wind (Liu et al., 2019) and water level (Brasil et al., 2016) have been linked to dominance of particular cyanobacteria species. Idealistic generalizations of species-specific environmental drivers are complicated by site-specific factors that characterize most studies and limit broader interpretations about interactions among species (Dokulil \& Teubner, 2000). This limitation points to the need for studies that synthesize relationships of cyanobacterial dominance with environmental conditions and habitats (see Rousso et al., 2020) and link trophic level and climatic region.

Dominance metrics are commonly used to characterize and quantify the dominant species in a community (McNaughton, 1967). Cyanobacteria species dominance can be quantified by peaks in numbers of individuals (cell counts) (Fernández et al., 2015), relative abundance of cells (Zhang et al., 2021) and biomass (biovolume) (Amorim et al., 2020; Yang et al., 2016). The choice of cell counts or biomass may yield different interpretations of dominance because of the wide range of sizes of cyanobacteria cells (Hillebrand et al., 1999). Cell size has also been proposed as a phytoplankton functional group trait (Cloern, 2018; Gallego et al., 2019), with a consensus that smaller phytoplankton (e.g. picocyanobacteria) have lower nutritional requirements and, thus, may outcompete species with large cells when nutrients are strongly limiting (Andersson et al., 2015; Callieri \& Stockner, 2000). Picocyanobacteria have traditionally received less attention than larger cyanobacteria species, partly because previous work has incorrectly assumed that species within this group do not produce toxins (Jasser \& Callieri, 2017). 
The aim of this research was to identify correlations of cyanobacterial community diversity, succession and dominance with environmental variables using long-term monitoring data from three important Australian drinking water reservoirs. These reservoirs provide a range of trophic levels, morphological characteristics (e.g. surface area, maximum depth) and mixing regimes, which provide insights into the relevance of the cyanobacterial alert level framework, and management and monitoring strategies. Our focus was specifically on the drivers of, and interactions among, cyanobacteria species within phytoplankton communities.

\section{Methodology}

Locations and data

Cyanobacteria cell counts and biovolumes from three drinking reservoirs in Australia (Fig. 1) were assessed through analysis of routine monitoring data collected by water utilities responsible for their management.

Lake Wivenhoe $\left(27^{\circ} 18^{\prime} \mathrm{S}, 152^{\circ} 32^{\prime} \mathrm{E}\right)$ is a eutrophic, monomictic drinking water reservoir in subtropical Southeast Queensland, Australia. It has a surface area of $109 \mathrm{~km}^{2}$, maximum depth of $38 \mathrm{~m}$ and storage of 1,165,000 ML at full supply level (FSL). Lake Tingalpa $\left(27^{\circ} 32^{\prime} \mathrm{S}, 153^{\circ} 10^{\prime} \mathrm{E}\right)$ is a shallow meso-eutrophic polymictic drinking reservoir, also located in Southeast Queensland. It has surface area of $4.7 \mathrm{~km}^{2}$, mean depth of $5.3 \mathrm{~m}$, and maximum storage of $13,206 \mathrm{ML}$ at FSL. Lake Myponga $\left(35^{\circ} 24^{\prime} \mathrm{S}, 138^{\circ}\right.$ $25^{\prime}$ E) is a meso-eutrophic monomictic drinking reservoir located in South Australia. It has a surface area of $2.8 \mathrm{~km}^{2}$, maximum depth of $43.9 \mathrm{~m}$ and maximum storage capacity of $26,800 \mathrm{ML}$ at FSL.

We analysed data from the closest sampling point to the dam wall in each reservoir. For Lake Myponga, data from a second sampling point close to the dam wall were also included when it was necessary to substitute missing data from the dam wall site. Sampling points were labelled with the first letter of the name of the reservoir followed by the number 1 , with the upstream station assigned 2 in Myponga (Fig. 1).

Water quality data comprised 5 years (2014-2018) for Lake Wivenhoe, 15 years (2004-2018) for Lake Tingalpa and 12 years (2008-2019) for Lake
Myponga. Water samples were taken by integrated tube from the water surface to 5-m depth for all lakes, usually between 08:00 and 10:00 h. The sampling frequency was monthly for Lake Wivenhoe and was usually monthly for Lake Tingalpa but less frequent in some instances. In Lake Myponga, sampling frequency was weekly in summer, autumn and spring but decreased to every other month during winter.

Water quality data comprised total phosphorus (TP), filterable reactive phosphorus $\left(\mathrm{PO}_{4}{ }^{3-}-\mathrm{P}\right)$, total nitrogen (TN), total Kjeldahl nitrogen (TKN), ammonium $\left(\mathrm{NH}_{4}{ }^{+}-\mathrm{N}\right)$ and nitrate $\left(\mathrm{NO}_{3}{ }^{-}-\mathrm{N}\right)$. In cases when TN or TKN was missing, they were calculated as $\mathrm{TN}=\mathrm{TKN}+\mathrm{NO}_{3}{ }^{-}-\mathrm{N}$.

Cyanobacteria data included cell counts and biovolume for the total cyanobacteria community and for individual cyanobacteria species or genera. Cell counts were estimated through microscopy. Taxonomic resolution was at species level but in several instances, resolution was limited to genus (e.g. Raphidiopsis spp.). Biovolume was estimated from geometric shape and size of each species or genus, including categorization of some genera by morphology (e.g. Dolichospermum spp. (straight) and Dolichospermum spp. (coiled)) or size (Aphanocapsa spp. $<2 \mu \mathrm{m}$ and Aphanocapsa spp. $>2 \mu \mathrm{m}$ ). In some instances, biovolume measurements were not available to complement cell counts and were calculated using relationships between cell counts and biovolume for each identified cyanobacteria species or genus (Supplementary Material A). These relationships were developed using all available data from all sampling points in all three lakes over the entire study period.

Sites W1 in Lake Wivenhoe and T1 in Tingalpa were equipped with a vertical profiling system (VPS), in which an EXO2 sensor (YSI, Yellow Springs, OH, USA) measured temperature hourly at 1-m depth intervals. In Lake Myponga, a VPS was located at M2, with the VPS surface water temperature at this site closely correlated with manual surface temperature measurements at site M1 $\left(R^{2}=0.98\right.$, Supplementary Material B). Temperature measurements from M2 were, therefore, extrapolated to M1. Mixers and aerators are deployed close to M1 and M2 by SA Water. These are designed to minimize vertical differences in temperature and reduce the incidence of surface cyanobacteria accumulations (see Lewis et al., 2002). 


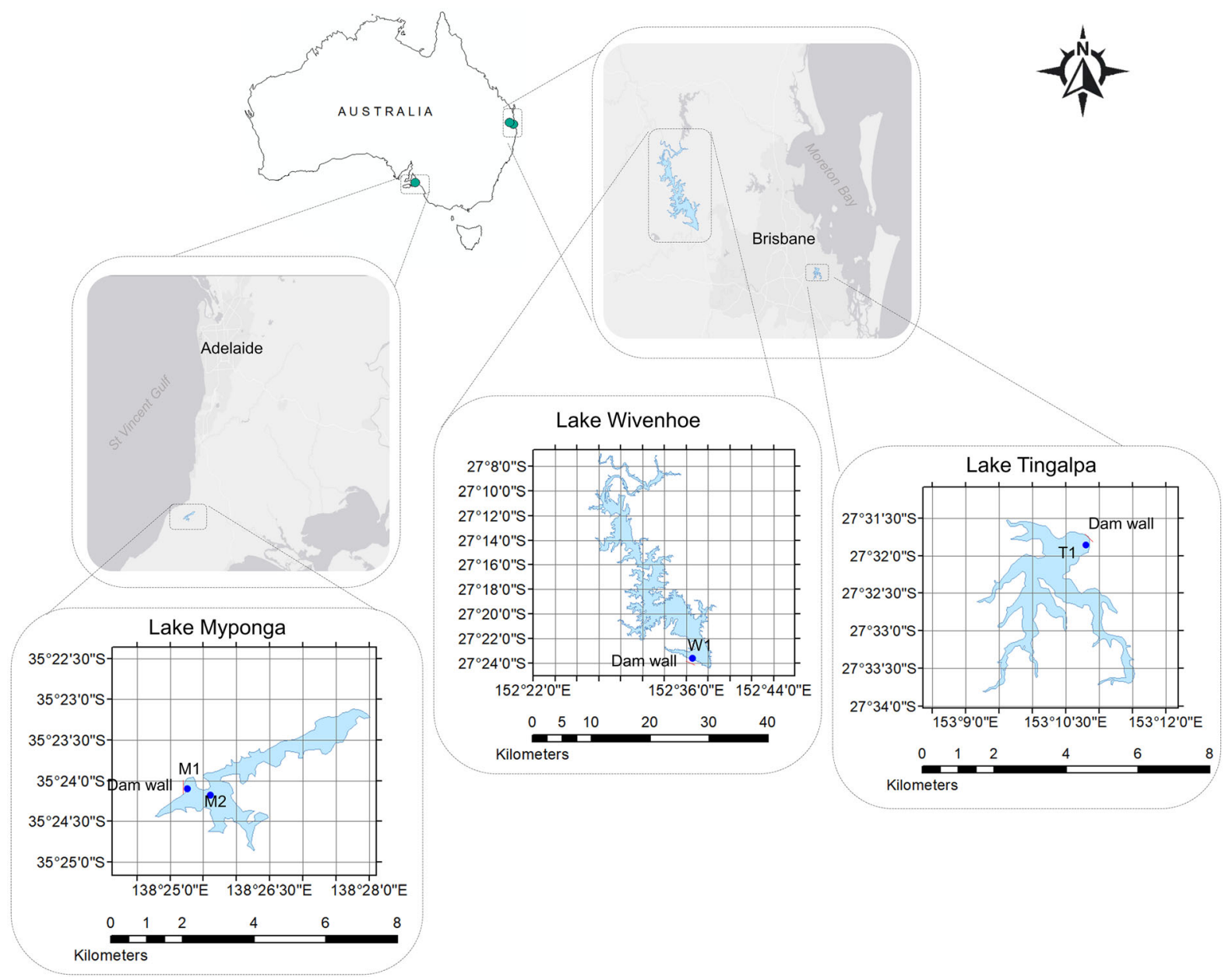

Fig. 1 Location of the three drinking water reservoirs. Blue circles indicate sampling points in the lakes, and red lines indicate the dam wall of each reservoir

Data processing and statistical analysis

Data were processed using $R$ 4.0.2 (R Core Team, 2020). Data were filtered to cases where at least $90 \%$ of total cyanobacteria (TC) cell counts were discretized in individual species to assure that the identified cyanobacteria species were representative of the entire cyanobacteria community diversity.

Cyanobacteria population metrics were assessed using Shannon evenness index $(\mathrm{H})$, Simpson dominance index (D) and Berger-Parker dominance index (BG) (Beisel et al., 1996; Spellerberg \& Fedor, 2003) for cell counts (i.e. $H_{\mathrm{cc}}, D_{\mathrm{cc}}$ and $\mathrm{BG}_{\mathrm{cc}}$, respectively) and biovolume (i.e. $H_{\mathrm{bv}}, D_{\mathrm{bv}}$ and $\mathrm{BG}_{\mathrm{bv}}$, respectively).

Schmidt stability index, metalimnion depth, epilimnion temperature and hypolimnion temperature were assessed from VPS temperature profiles using rLakeAnalyzer (Winslow et al., 2019). The metalimnion layer for all lakes was frequently below the vertical resolution of temperature measurements $(<0.5 \mathrm{~m})$; thus, for this study, the upper and lower metalimnion depths were averaged and the result is henceforth termed metalimnion depth.

Spearman non-parametric correlation and Principal Component Analysis (PCA) were calculated using $R 4.02$ base functions (R Core Team, 2020) Spearman non-parametric correlation was used because data did not conform to Gaussian normal distributions and variables were not linearly correlated (Hauke \& Kossowski, 2011). Measurements were standardized (mean $=0$, standard deviation $=1$ ) before testing, to avoid bias due to units specific to each variable. The 
significance level adopted was $P<0.05$. Reported correlations henceforth were significant at this level, otherwise they are stated as non-significant. Plots were generated using corrplot (Wei \& Simko, 2017) and factoextra (Kassambara \& Mundt, 2020) $R$ packages.

Seasonality was assessed through categorization of samples by seasons. This study was conducted in the southern hemisphere; thus, summer is from December to February, autumn from March to May, winter from June to August and spring from September to November.

\section{Results}

Cyanobacteria dynamics and concentration

Cyanobacteria richness varied considerably among lakes. Lake Wivenhoe had the highest number of species with 65 cyanobacteria genera, followed by Lake Tingalpa (46) and Lake Myponga (15). Around $60 \%$ of the identified cyanobacteria species in the lakes were classified as unicellular picocyanobacteria $(<2 \mu \mathrm{m})$, while the remaining $40 \%$ were mostly colonial and filamentous species.

Dominance indices BG (Berger-Parker) and $D$ (Simpson) were strongly positively correlated $(\rho>0.98)$ for all assessed locations (Supplementary Material C). Both indices were strongly negatively correlated with $H$ (Shannon evenness index; $\rho<-0.99)$. $\mathrm{H}$ values in Lake Wivenhoe were consistently higher than in Lake Tingalpa and Lake Myponga, indicating a more diverse cyanobacterial community (Table 1).

The determination of the dominant species differed between biovolume and cell counts. $\mathrm{BG}_{\mathrm{cc}}$ and $D_{\mathrm{cc}}$ dominant species (i.e. based on cell counts) differed most from $\mathrm{BG}_{\mathrm{bv}}$ and $D_{\mathrm{bv}}$ dominant species (i.e. based on biovolume) when cyanobacterial richness was high (e.g. Lake Wivenhoe, Fig. 2a, only BG reported), usually when picocyanobacteria contributed strongly to the $\mathrm{BG}_{\mathrm{cc}}$ and $D_{\mathrm{cc}}$ indices at the same time that cyanobacteria with large cells contributed strongly to $\mathrm{BG}_{\mathrm{bv}}$ and $D_{\mathrm{bv}}$ (Fig. 2b, only BG reported). Disagreement also occurred at lower frequency when large-cell cyanobacteria species were dominant (e.g. $\mathrm{BG}_{\mathrm{cc}}$ dominated by Microcystis spp. and $\mathrm{BG}_{\mathrm{bv}}$ dominated by Raphidiopsis spp).
All analyses of environmental drivers and intracommunity correlations were conducted using biovolume as metric for cyanobacteria concentration rather than cell counts. $\mathrm{BG}_{\mathrm{bv}}$ and $D_{\mathrm{bv}}$ dominance indices were strongly correlated $(\rho>0.98)$ so only one metric (BG) was chosen for further comparisons with environmental drivers.

Cyanobacterial richness was significantly positively correlated $(P \leq 0.05)$ with total cyanobacteria biovolume for Lake Wivenhoe $(\rho=0.480)$ and Lake Myponga $(\rho=0.181)$ but not for Lake Tingalpa $(P>0.05)$. Interestingly, in all lakes, total cyanobacterial biovolume was not significantly correlated with $\mathrm{BG}_{\mathrm{bv}}$ or $D_{\mathrm{bv}}$. Cyanobacterial richness was positively correlated with epilimnion temperature (Lake Wivenhoe, $\rho=0.550 ;$ Lake Tingalpa, $\rho=0.764$; Lake Myponga, $\rho=0.614$ ) and $H_{\mathrm{bv}}$ (Lake Wivenhoe, $\rho=0.843, P<0.05$; Lake Tingalpa, $\rho=0.920$; Lake Myponga, $\rho=0.973$ ) and negatively correlated with dominance indices $\mathrm{BG}_{\mathrm{bv}}$ (Lake Wivenhoe, $\rho=-0.671$; Lake Tingalpa, $\rho=-0.859$; Lake Myponga, $\rho=-0.573$ ) and $D_{\mathrm{bv}}$ (Lake Wivenhoe, $\rho=-0.723$; Lake Tingalpa, $\rho=-0.864$; Lake Myponga, $\rho=-0.574$ ).

Across the lakes, there were significant positive correlations of total cyanobacteria biovolume to nitrogen, phosphorus, epilimnion temperature and/or stratification indices (Supplementary Material C). Throughout the monitoring period, none of the lakes had median total cyanobacteria biovolume $>0.3$ $\mathrm{mm}^{3} / 1$ (Table 1), i.e. Alert Level 1, but all had maximum total cyanobacteria biovolume $>4 \mathrm{~mm}^{3} / 1$; Alert Level 2 of the World Health Organization (WHO) guidelines (Chorus \& Welker, 2021). In Lake Myponga, total cyanobacteria biovolume was positively correlated with TP $(\rho=0.274)$, TKN $(\rho=0.276)$ and $\mathrm{TN}(\rho=0.176)$, and negatively correlated with $\mathrm{NO}_{3}{ }^{-}-\mathrm{N} \quad(\rho=-0.307)$. Total cyanobacteria biovolume was not significantly correlated with water temperature, Schmidt stability or metalimnion depth in this lake. Among the three lakes, Lake Myponga had the highest total cyanobacteria cell counts and biovolumes, concomitantly with the highest maximum and average TP and TN concentrations over the study period (Table 1). For Lake Tingalpa, total cyanobacteria biovolume was closely correlated with Schmidt stability $(\rho=0.766)$ and metalimnion depth $(\rho=0.753)$. In Lake Wivenhoe, total cyanobacteria biovolume was positively correlated with 


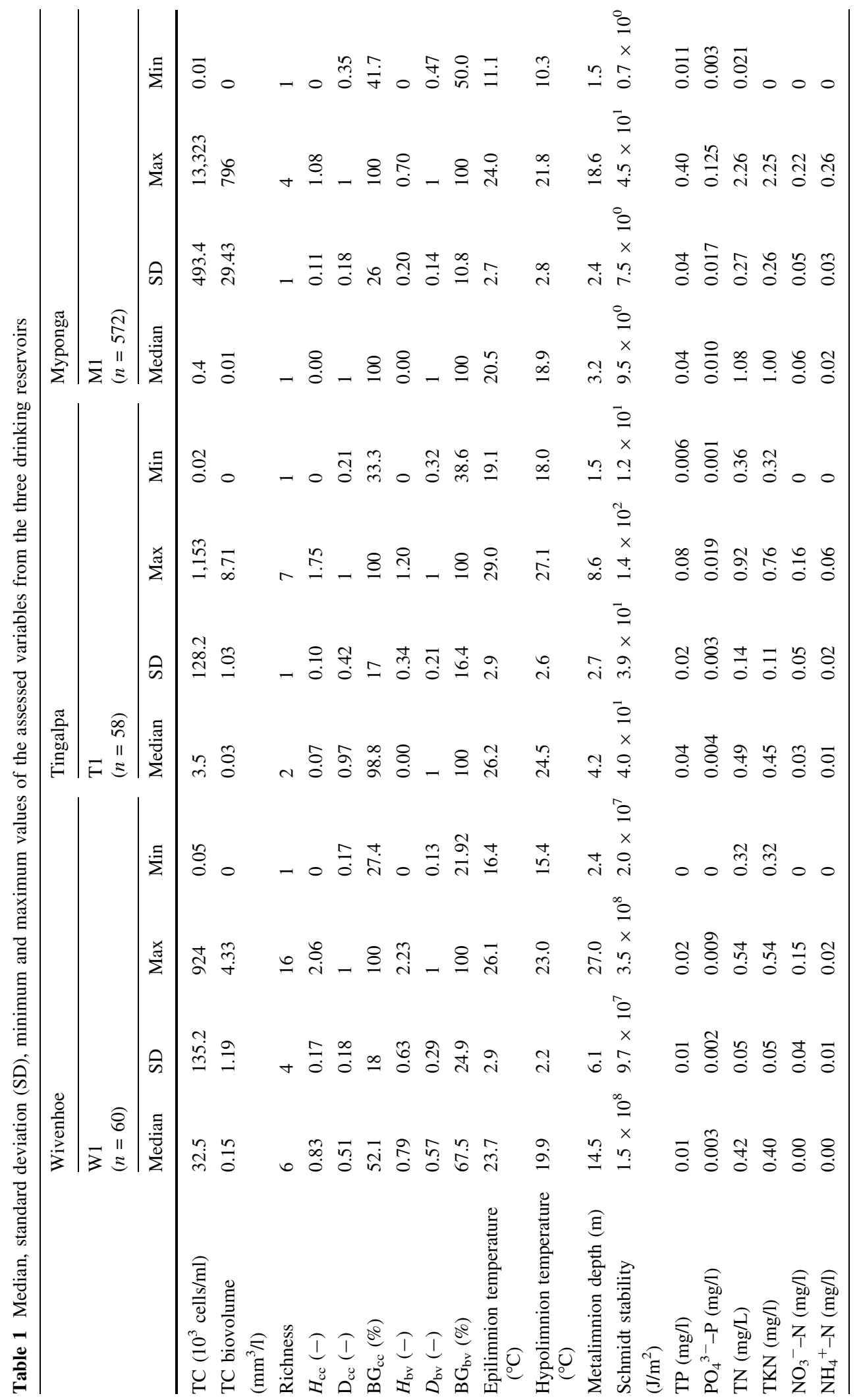




\section{a)}
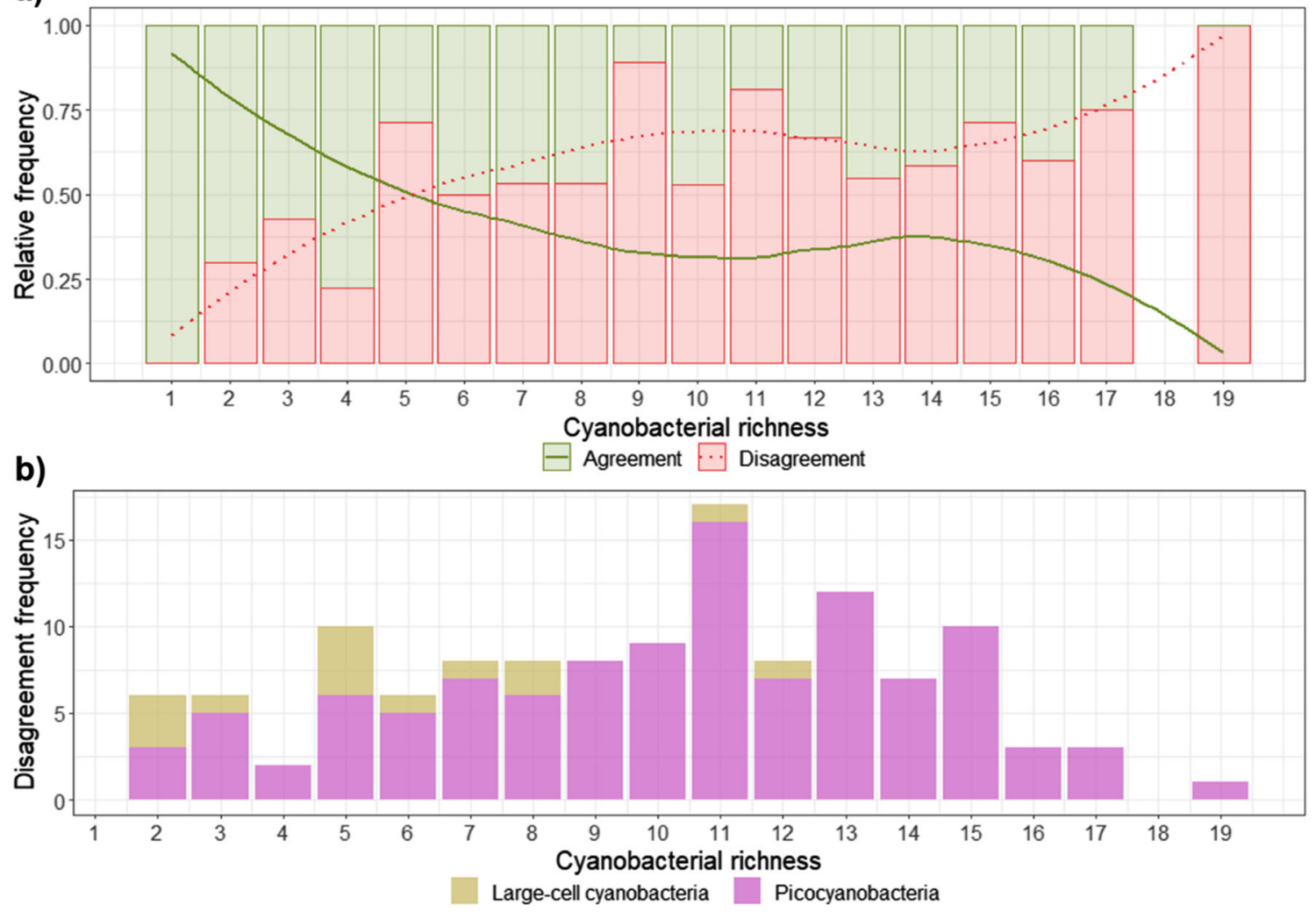

Fig. 2 Comparison between dominant cyanobacteria species using either cell counts $\left(\mathrm{BG}_{\mathrm{cc}}\right)$ or biovolume $\left(\mathrm{BG}_{\mathrm{bv}}\right)$ for $\mathrm{BG}$ dominance index calculation at Lake Wivenhoe. a Relative frequency of agreement or disagreement of $\mathrm{BG}_{\mathrm{bv}}$ and $\mathrm{BG}_{\mathrm{cc}}$ with cyanobacterial richness, where agreement represents cases when both $\mathrm{BG}_{\mathrm{bv}}$ and $\mathrm{BG}_{\mathrm{cc}}$ resulted in the same species as dominant while disagreement indicates cases when dominant

Schmidt stability $(\rho=0.561)$, TP $(\rho=0.323)$ and TKN $(\rho=0.464)$.

Cyanobacteria succession, based on changes in $\mathrm{BG}_{\mathrm{bv}}$ and $\mathrm{BG}_{\mathrm{cc}}$, showed strong seasonality in Lake Wivenhoe (Fig. 3). The larger cyanobacteria species (e.g. Raphidiopsis spp., Pseudanabaena spp. and Planktolyngbya limnetica (Lemmermann) Komárková-Legnerová \& Cronberg) were dominant on different occasions in this lake from late spring to early autumn, while picocyanobacteria (Aphanocapsa spp., Cyanocatena spp. and Cyanogranis spp.) usually dominated in winter. In Lakes Myponga and Tingalpa (Supplementary Materials D and E) cyanobacteria succession varied with season but not as strongly as in Lake Wivenhoe. In Lake Tingalpa, dominance similarly alternated between picocyanobacteria and larger cyanobacteria, but seasonal patterns were less evident. species were different. Bars denote the ratio of agreement and disagreement for each cyanobacterial richness and the lines represent the trend of the ratio with increasing species richness. b Frequency of disagreement between $\mathrm{BG}_{\mathrm{cc}}$-dominant cyanobacteria and $\mathrm{BG}_{\mathrm{bv}}$-dominant species for cyanobacterial richness

In Lake Myponga, Microcystis spp. and Dolichospermum circinale (Rabenhorst ex Bornet \& Flahault) Wacklin, Hoffmann \& Komárek were the dominant species, with Microcystis spp. mostly dominating from late spring to mid-summer and $D$. circinale from late summer to early autumn.

Species dominance and shifts due to environmental conditions

The relationship of water temperature and nutrients to species dominance varied among the lakes. In Lake Wivenhoe, total cyanobacteria biovolume and dominance $\left(\mathrm{BG}_{\mathrm{bv}}\right)$ were positively correlated with water temperature for some larger species (Raphidiopsis spp., Pseudanabaena spp. and Planktolyngbya limnetica). 


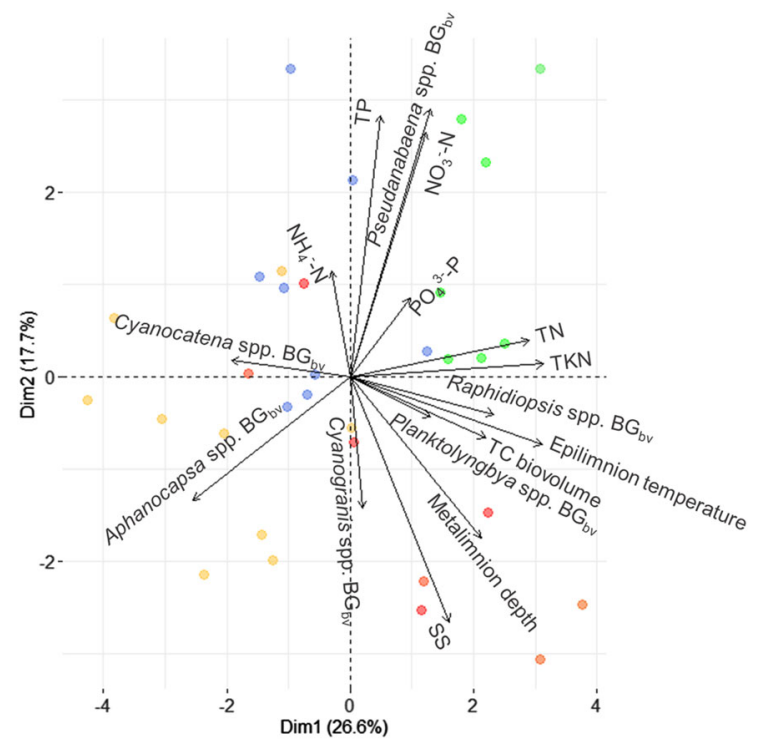

Fig. 3 Principal Component Analysis for Lake Wivenhoe differentiated by season. Length of arrows represents how well the variable is aligns with the displayed principal components. Coloured points denote the season: red $=$ summer, yellow $=$ autumn, blue $=$ winter and green $=$ spring

In Lake Tingalpa, total cyanobacteria biovolume was positively correlated with water temperature (Supplementary Material C). Total cyanobacteria cell counts were negatively correlated with nutrients (TP, $\rho=-0.580 ; \quad \mathrm{TN}, \quad \rho=-0.397 ; \quad \mathrm{NH}_{4}{ }^{+}-\mathrm{N}$, $\left.\rho=-0.739 ; \mathrm{NO}_{3}-\mathrm{N}, \rho=-0.690\right)$ and higher total cyanobacteria cell counts occurred when the $\mathrm{BG}_{\mathrm{bv}}$ was elevated due to the picocyanobacteria Aphanocapsa spp. or Cyanocatena spp. In contrast, total cyanobacteria biovolume was high during periods of Microcystis spp. dominance, resulting in a positive correlation between total cyanobacteria biovolume and Microcystis spp. $\mathrm{BG}_{\mathrm{bv}}(\rho=0.561)$. Microcystis spp. $\mathrm{BG}_{\mathrm{bv}}$ was negatively correlated with picocyanobacteria $\mathrm{BG}_{\mathrm{bv}}\left(\mathrm{BG}_{\mathrm{bv}}\right.$ Microcystis spp. vs $\mathrm{BG}_{\mathrm{bv}}$ Aphanocapsa spp., $\rho=-0.561$ ). Microcystis spp. $\mathrm{BG}_{\mathrm{bv}}$ was usually associated with high TP (Supplementary Material D), although there were no significant correlations $(P>0.05)$ between these variables (Supplementary Material C).

In Lake Myponga, D. circinale or Microcystis spp. often dominated total cyanobacteria cell counts and biovolumes. Microcystis spp. and D.circinale succession (biovolume and cell counts) were correlated with Schmidt stability and metalimnion depth, but there was no relationship between total cyanobacteria biovolume and Schmidt stability, metalimnion depth or water temperature (see Sect. 3.1). D. circinale $\mathrm{BG}_{\mathrm{bv}}$ was negatively correlated with Schmidt stability $(\rho=-0.297)$ and metalimnion depth ( $\rho=-0.416$ ), while Microcystis spp. $\mathrm{BG}_{\mathrm{bv}}$ was positively correlated with epilimnion and hypolimnion temperature ( $\rho=0.561, \rho=0.575$, respectively) (Supplementary Materials C and D).

For diazotrophic species, relationships of $\mathrm{BG}_{\mathrm{bv}}$ with $\mathrm{NO}_{3}{ }^{-} \mathrm{N}$ were variable, both positive and negative, e.g. $\rho=0.383$ for Pseudanabaena in Lake Wivenhoe and $\rho=-0.304$ for $D$. circinale in Lake Myponga. TN was also positively correlated with $\mathrm{BG}_{\mathrm{bv}}$, with some larger cell, non-diazotrophic species such as P. limnetica ( $\rho=0.330$ in Lake Wivenhoe), Pseudanabaena spp. ( $\rho=0.382$ in Lake Wivenhoe) and Microcystis spp. ( $\rho=0.502$ in Lake Tingalpa; $\rho=0.148$ in Lake Myponga). In contrast, $\mathrm{NH}_{4}{ }^{+}-\mathrm{N}$ and $\mathrm{PO}_{4}{ }^{3-}-\mathrm{P}$ were not correlated with biovolume dominance for any of the species (i.e. $\mathrm{BG}_{\mathrm{bv}}$ ).

Dominance of picocyanobacteria was generally associated with lower total cyanobacteria biovolume compared with periods of dominance by large-cell cyanobacteria. This dominance coincided with lower $\mathrm{TN}$ and $\mathrm{NO}_{3}{ }^{-}-\mathrm{N}$ concentration, lower temperature and weakly stratified waters, usually corresponding to winter. Dominance of larger cyanobacteria was commonly associated with higher total cyanobacteria biovolume, and elevated concentration of TP, TN and TKN across all lakes. In contrast to the picocyanobacteria, larger cyanobacteria $\mathrm{BG}_{\mathrm{bv}}$ correlations with Schmidt stability, epilimnion temperature, metalimnion depth and cyanobacterial richness were equivocal and varied across the lakes (Table 2).

\section{Discussion}

Diversity during cyanoHABs

Dominance indices for cyanobacteria species often varied between cell counts and biovolume. Cell biovolume varies by orders of magnitude among species (Jasser \& Callieri, 2017), and in our study, picocyanobacteria and larger cyanobacteria were responsible for most of the variation in dominance indices between cells and biovolume (Fig. 2). Updates in cyanobacteria alert level frameworks (Chorus \& Welker, 2021) have changed threshold levels to 
biovolume instead of cell counts to reflect that biovolume is a better predictor of toxicity than cell counts. Based on our results, cyanobacteria and phytoplankton diversity indexes should be calculated using either biovolume or biomass, to avoid misinterpretations of environmental outcomes (e.g. toxicity) with cell counts or relative abundance.

We focused exclusively on variations in cyanobacteria within the phytoplankton community. Cyanobacteria biovolume was not significantly correlated with any of the diversity indexes H, D or BG. Richness generally increased with total cyanobacteria biovolume in all three lakes except when there was high biovolume at Myponga. The observed increase in cyanobacteria richness by lake area is similar to previous findings of increase in local and regional zooplankton species richness with landscape area (Shurin et al., 2000). However, the limited number of assessed lakes in this study hinders further generalization. More than one cyanobacterial species was often present when Alert Level 1 cyanobacteria biovolume $\left(0.3 \mathrm{~mm}^{3} / \mathrm{l}\right)$ was exceeded in Lakes Wivenhoe and Tingalpa, while in Lake Myponga monospecies dominance was commonly observed. Co-occurrence of multiple cyanobacteria species has been noted in cyanoHABs from different waterbodies and climatic regions as well as with different trophic states (e.g. Amorim et al., 2020; Chellappa \& Costa, 2003; Zamyadi et al., 2021). It has been related to similarities in niche and fitness among species, mostly due to size differences (Gallego et al., 2019). We found that when picocyanobacteria dominated, larger cyanobacteria species were not present, but when larger cyanobacteria dominated, they tended to coexist with picocyanobacterial, albeit at reduced levels. Conversely, there can be successions of cyanoHAB species that form monospecific blooms (e.g. Jiang et al., 2017; Vanderley et al., 2021). Tromas et al. (2017) analysed the diversity of the bacterial community in eutrophic Lake Champlain, Canada, through genomic sequencing and observed that the relative abundance of non-dominant cyanobacteria decreased preceding a cyanoHAB while cyanobacterial richness did not.

Cyanobacterial diversity and richness may also be related to nutrient availability, as observed in Donqian Lake, China, where a significant decrease in richness was attributed to nutrient reduction following sediment dredging (Jing et al., 2013), although decreased recruitment from overwintering or akinete sources may be possible. Interaction with other organisms can also affect cyanobacteria diversity during cyanoHABs (Amorim \& Moura, 2021; Bockwoldt et al., 2017; Chellappa \& Costa, 2003), with findings of positive correlations of cyanobacteria richness with other prokaryotes (Song et al., 2017; Zhang et al., 2021), and with zooplankton grazing and fish predation (Ekvall et al., 2014; Ger et al., 2014; Lampert, 1987; Urrutia-Cordero et al., 2015). We lacked data to test such responses in our study.

Environmental correlations

Highest cyanobacteria concentrations were often observed from late spring to early autumn for all three studied lakes. Increased daily solar radiation and a shallow mixed layer depth usually increase cyanobacterial biomass in warm seasons (Chorus \& Welker, 2021) while higher water temperature and cyanobacteria growth rate also contribute to such increases (Lürling et al., 2013; Robarts \& Zohary, 1987), but many other, often interacting, factors can be important, such as thermal stratification and external and internal nutrient loading (Carey et al., 2012).

In our study, TP was positively correlated with total cyanobacteria biomass in Lake Wivenhoe and Myponga, supporting findings from previous studies (Carvalho et al., 2013; Rigosi et al., 2015). Shifts in cyanobacterial dominance within communities may be related to changes in TP:TN ratio (Zhang \& Rao, 2012) combined with specific traits of cyanobacteria (e.g. diazotrophy; organic $\mathrm{P}$ and high-affinity $\mathrm{P}$ uptake, alkaline phosphatase activity and vertical migration) (Li et al., 2020). Rapid assimilation of $\mathrm{P}$ means cyanobacteria compete effectively for $P$ against other bacteria (Chorus \& Welker, 2021) and luxury storage of $\mathrm{P}$ can support up to four cell divisions in some cyanobacteria, which may explain the absence of correlations between $\mathrm{PO}_{4}{ }^{3-}-\mathrm{P}$ and total cyanobacteria biovolume. Low levels of dissolved inorganic nitrogen (i.e. $\mathrm{NO}_{3}{ }^{-}-\mathrm{N}, \mathrm{NO}_{2}{ }^{-}-\mathrm{N}$ and $\mathrm{NH}_{4}{ }^{+}-\mathrm{N}$ ) have been associated with cyanobacterial dominance, particularly diazotrophic cyanobacteria (e.g. Dolichospermum spp.), over other species (Ferber et al., 2004), while colonial and vacuolated non-diazotrophic species (e.g. Microcystis) may take up $\mathrm{NH}_{4}{ }^{+}-\mathrm{N}$ from bottom waters when undergoing diel vertical migration cycles (Blomqvist et al., 1994). We found that 
Table 2 Correlations of cyanobacteria grouped by species dominance and specific traits (large/picocyanobacteria and diazotrophic/ non-diazotrophic) with environmental conditions for each lake

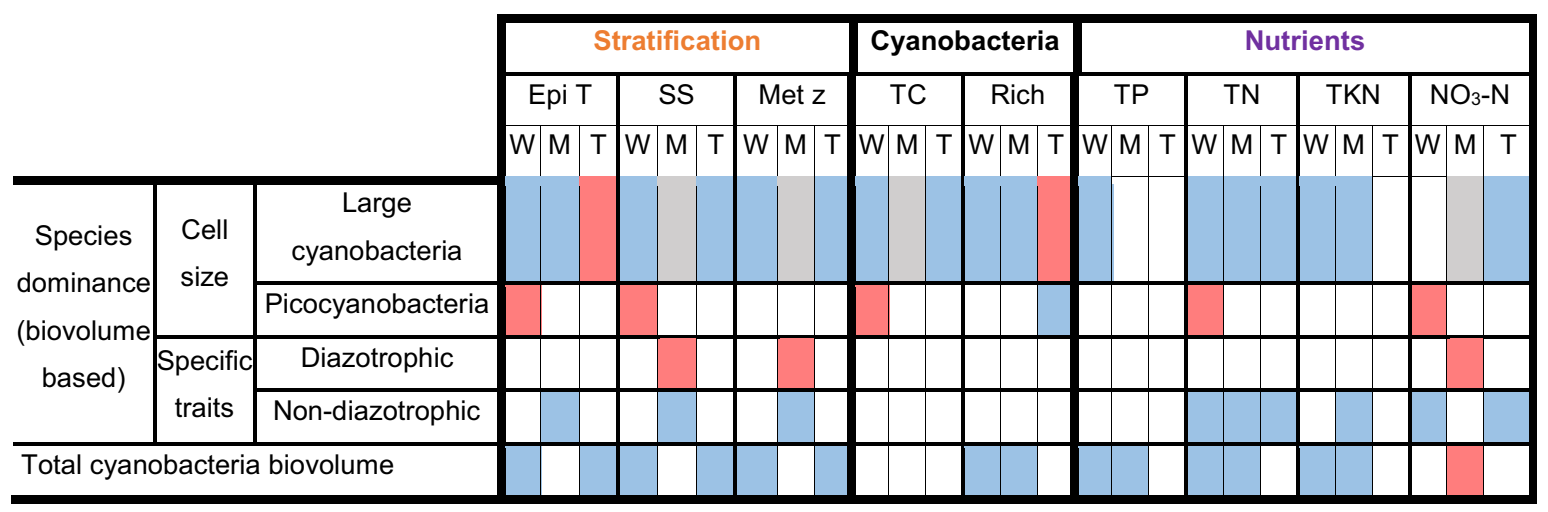

Blue, red and grey cells indicate positive, negative and 'equivocal' (i.e. variable depending on species within the group) correlations among variables for the specified lake. White cells indicate that no significant $(P>0.05)$ correlation was observed

Epi epilimnion temperature; SS Schmidt stability; Met Metalimnion depth; TC total cyanobacteria biovolume; Rich cyanobacteria richness; $T P$ total phosphorus; $T N$ total nitrogen; $T K N$ total Kjeldahl nitrogen; $\mathrm{NO}_{3}{ }^{-}-\mathrm{N}$ nitrate; $W$ Wivenhoe; $M$ Myponga; $T$ Tingalpa

non-diazotrophic species were more likely to be dominant at high $\mathrm{TN}$ and $\mathrm{NO}_{3}{ }^{-}-\mathrm{N}$ concentrations, while $D$. circinale dominated at low $\mathrm{NO}_{3}{ }^{-}-\mathrm{N}$ concentrations, similar to previous reports in the literature (Dokulil \& Teubner, 2000; Reynolds et al., 2002).

In our study, picocyanobacteria dominated in Lake Wivenhoe and Tingalpa during periods with low TN (Supplementary Material C) and multiple picocyanobacteria species frequently co-existed in Lake Wivenhoe and Tingalpa (e.g. Chroocaccales Aphanocapsa spp., Synechocaccales Cyanocatena spp.). Seasonal dominance or co-existence of several picocyanobacterial species has been observed in other regions when there is reduced nutrient availability (e.g. Lake Maggiore, Italy Callieri \& Stockner, 2000; Northern Baltic Sea, Andersson et al., 2015; and Lajes reservoir, Brazil, Rocha et al., 2019). Picocyanobacteria have small surface area to volume ratios favouring their competitiveness in low nutrient levels cyanobacteria (Wehr, 1989). The successful consortium between Chroocaccales (e.g. Aphanocapsa spp.) and Synechocaccales (e.g. Cyanocatena spp.) picocyanobacteria may arise from the ability of Synechocaccales diazotrophy and Chroocaccales to efficiently take up the excreted nitrogen from diazotrophic cyanobacteria (Andersso et al., 2015).

Large cyanobacteria species dominated biovolume in the lakes; Raphidiopsis spp. in Lake Wivenhoe,
Microcystis spp. in Lake Tingalpa, and Microcystis spp. and D. circinale in Lake Myponga) and increases often occurred concomitantly with decreases in picocyanobacteria biovolume except in Lake Myponga, where picocyanobacteria were rarely detected. In subtropical Lake Wivenhoe, Raphidiopsis spp. dominance was positively related to stratification intensity and epilimnion temperature that can be linked to warmer climates (Borics et al., 2000; Chellappa \& Costa, 2003; McGregor \& Fabbro, 2000). Raphidiopsis spp., P. limnetica and Pseudanabaena spp. often co-existed in Lake Wivenhoe, similar to picocyanobacteria observations in several other Australian drinking reservoirs (McGregor \& Fabbro, 2000) and a number of temperate lakes in Europe (Dokulil \& Mayer, 1996; Padisak, 1997). This co-existence has been attributed to similar ecological adaptations of shade tolerance and high $\mathrm{NH}_{4}{ }^{+}-\mathrm{N}$ uptake rate (Présing et al., 1996), which may lead to niche overlap. In Lake Myponga, Microcystis spp. and D. circinale successively dominated the cyanobacterial community. Microcystis spp. usually dominated from late spring to mid-summer while $D$. circinale usually dominated during the beginning of the cooling period in autumn. Microcystis spp. is slightly better adapted to higher temperatures than D.circinale (Bormans et al., 2005; Imai et al., 2009), while $D$. circinale can adapt to nitrogen scarcity through diazotrophy (Rigosi 
et al., 2014). The early seasonal dominance of Microcystis spp. in Lake Myponga may be related to the combination of an increase in temperature and higher nutrient availability. Prolonged thermal stratification during summer, despite the use of aerators and mixers, may decrease nitrogen availability, as observed in other studies (Yoshikawa \& Furuya, 2006) and favour the shift to dominance of D. circinale.

One of the limitations of our study was the limited temporal resolution of the data (i.e. based on sporadic grab samples). Limited temporal resolution may result in correlations that do not represent causation (i.e. the environmental drivers for cyanobacteria succession or blooms) because the data provide a single snapshot of a continuous and time-dependent process (Gardner, 2000), thus, requiring careful analysis and interpretation of the results taking into account previous environmental histories and knowledge on cyanobacteria ecology.

Implications for water monitoring and cyanoHAB management

Microscopy is still the most commonly employed method for monitoring cyanobacteria, despite being labourious and time consuming. Microscopic cell enumeration is often done to genus or species level, and biovolume may be obtained either directly from cell dimension measurements or indirectly from the literature. The standardization of cyanobacterial diversity analysis to biovolume or biomass units would facilitate comparison between different taxa, in accordance with a recently proposed framework for cyanoHABs management (Chorus \& Welker, 2021). Our study provides a brief resource based on the assessed data, that can be used for conversion between cell counts and biovolume (Supplementary Material A) in cases where site-specific data are not available.

The choice of management strategy to mitigate cyanoHAB risk is, among other factors, dependent on the dominant cyanobacteria species or trait-based group of cyanobacteria species. For instance, the relative control of nitrogen and phosphorus may vary depending on the need to control heterocystous versus non-heterocystous cyanobacteria (Agawin et al., 2007; Hamilton et al., 2016; Wan et al., 2019). Destratification of the water column can be employed to decrease the abundance of high-light dependent and buoyant cyanobacteria species (Visser et al., 2016), but long- term effects of this control should take into account adaptive features of cyanobacteria (e.g. Antenucci et al., 2005). Dosage of algicides to control cyanobacteria may vary according to the dominant species. In cases where colony-forming taxa dominate, higher dosages may be required because mucilage hinders the oxidizing effect of the algicide (Lürling et al., 2014). Application of algicides should be controlled since persistent use of algicides may favour the selection of resistant cyanobacteria species (Rouco et al., 2014), besides increasing the potential for impacts on other phytoplankton groups (Matthijs et al., 2012). The effectiveness of biomanipulation has been shown to vary according to the susceptiblity of cyanobacteria to predation (Urrutia-Cordero et al., 2016), sometimes associated with the presence of toxic colony-forming or filamentous species (Vanderploeg et al., 2001), and the ability to concurrently reduce nutrient loads (Peretyatko et al., 2012). Cyanobacteria removal in drinking water treatment plants is also specific to the species and the treatment process (Pazouki et al., 2016; Zamyadi et al., 2021). Cases where multiple cyanobacteria species co-exist and successively dominate, as observed in our results for Lakes Wivenhoe and Tingalpa, pose an increased challenge for drinking water treatment plant operators (Zamyadi et al., 2013) and control strategies are often set at genus level.

Identification and quantification of cyanobacterial community composition in a fast, reliable and costefficient manner is crucial for proactive cyanoHAB management. Genomic and molecular based methods (see Moreira et al. 2014 for a review) provide a detailed characterization and quantification of cyanobacterial taxa beyond morphological-based enumeration and classification, and include identification of toxic strains (D'Agostino et al., 2016), but can be costly. Flow cytometry may also allow rapid quantification of cyanobacteria abundance and biovolume, including in situ deployments (Havlik et al., 2013; Pomati et al., 2013) and reduced bias in biovolume estimates by negating use of chemical preservatives for cell storage or immobilization (Hawkins et al., 2005). Recent machine learning applications may allow flow cytometry to differentiate phytoplankton to species level, including for cyanobacteria. For instance, convolutional neural networks, a deep learning technique, were employed to differentiate 80 diatoms species (Pedraza et al., 2017) with 99.5\% of accuracy when flow cytometry training samples are 
large. Samples with Microcystis aeruginosa, Microcystis wesenbergii, Oscillatoria sp., Aphanizomenon sp. and Dolichospermum sp. have been systematically classified and enumerated using similar deep learning algorithms combined with flow cytometry (Baek et al., 2020). Other machine learning applications have been used to optimize flow cytometry measurements, including biovolume and cell counts of phytoplankton functional groups (Thomas et al., 2018), with high quantitative similarity between flow cytometry and microscopy estimates.

Other technologies, based primarily on sensors tuned to optical proprieties of phycocyanin or phycoerythrin, can provide high temporal and spatial resolution of cyanobacteria biomass in real time and should be calibrated against cyanobacteria biovolume rather than cell counts (Rousso et al., 2022, Bertone et al., 2018, 2019). These sensors may be useful for proactive cyanoHAB management but trade off precision (e.g. species or taxon resolution) and potentially accuracy (e.g. due to interferences) against rapid population-level biomass assessment. Hyperspectral remote sensing focusing on phycocyanin reflectance can provide high cost-efficient spatial estimates of total cyanobacteria over extended areas. However, it also does not differentiate cyanobacteria to species level and requires careful species-specific validation and ground truthing based on direct measurements of biomass. Cyanobacteria communities are often composed by multiple species, which should be reflected in the calibration of optical sensors and, where possible, use of multiple cross-validation methods. Optimization of fluorescence sensors through machine learning can assist in this field of research, including detection of anomalies to trigger management responses (Almuhtaram et al., 2021) and correction of lightinduced fluorescence quenching (Lucius et al., 2020; Rousso et al., 2021). The application of machine learning techniques to predict cyanobacteria species dominance based on environmental conditions has been suggested as a way to improve calibration of fluorescence sensors and to provide species-specific information in real time to support improved cyanoHAB management (Rousso et al., 2020). This approach would still rely on species identification through other methods and comprehensive historical data to develop predictive models. Nevertheless, as highlighted by Simis et al. (2007), some monitoring methods have intrinsic limitations and we should aim to strategically complement them. Comprehensive cyanoHABs monitoring plans should, therefore, encompass a range of methods aiming to integrate precise strains and species identification to support species-targeted responses, and autonomous methods that generally provide community level assessments and allow fast and proactive responses from water managers.

\section{Conclusions}

An analysis of long-term routine monitoring data from three Australian drinking reservoirs was conducted to examine relationships of cyanobacteria intra-community diversity and dominance to water quality and stratification parameters. Diversity analysis of cyanobacteria populations quantified dominance indexes using species cell counts or biovolume. Cell counts for cyanobacterial dominance calculations result in overestimation of picocyanobacteria dominance over other cyanobacteria due to their small cell size. We recommend that biovolume or biomass is used for phenological assessments of cyanobacteria, which aligns with recent Alert Level Frameworks for cyanoHABs assessment risk.

The two subtropical lakes included in this study had higher cyanobacterial diversity than the lake in the temperate region. In the subtropical lakes, picocyanobacteria (Aphanocapsa spp., Cyanocatena spp. and Cyanogranis spp.) and large-cell, colonial and filamentous cyanobacteria (Raphidiopsis spp., Pseudanabaena spp., Microcystis spp.) often had alternate periods of dominance, with picocyanobacteria dominant when nutrients were low, and colonial and filamentous cyanobacteria dominant during warmer, nutrient-rich conditions, particularly when phosphorus concentrations were higher. In temperate Lake Myponga with lower cyanobacterial diversity, Microcystis spp. dominated during warm and nitrogen-rich conditions, followed by $D$. circinale in late summer as nitrogen concentrations and water temperature decreased. Among larger cyanobacteria species, nondiazotrophic species dominated during periods with high inorganic $\mathrm{N}$ and diazotrophic species dominated at low $\mathrm{N}$ concentrations. Total cyanobacteria biovolume tended to be higher when water temperature and total phosphorus concentrations were elevated. Our results indicate that reduction of nutrient loading in 
lakes may reduce total cyanobacteria concentration and favour a shift to picocyanobacteria, but targeted reductions of nitrogen and phosphorus should be considered as they could affect the abundance and proportions of non-diazotrophic and diazotrophic species.

Cyanobacteria richness frequently increased with total cyanobacteria biomass, indicating that multiple species can co-exist during cyanoHABs, which challenges targeted species-specific management responses. CyanoHABs management should encompass comprehensive monitoring plans that provide adequate temporal, spatial and taxa precision to support targeted and proactive prevention or treatment responses. Analysis of routine monitoring data in our study can support a site-specific understanding of cyanobacteria dynamics, which is crucial for cyano$\mathrm{HAB}$ prevention and mitigation, but combinations of one or more monitoring methods with machine learning applications could be used to optimize species-specific cyanoHAB management.

Acknowledgements This study was supported by a Griffith University Postgraduate Research Scholarship (GUPRS) and a Griffith University International Postgraduate Research Scholarship (GUIPRS).

Author contributions All authors have seen and approved the final version of the manuscript being submitted. They warrant that the article is the authors' original work, has not been published before and is not under consideration for publication elsewhere.

Funding Open Access funding enabled and organized by CAUL and its Member Institutions. This research was supported by a Griffith University Postgraduate Research Scholarship (GUPRS) and a Griffith University International Postgraduate Research Scholarship (GUIPRS).

Data availability Not applicable.

Code availability Not applicable.

\section{Declarations}

Conflict of interest The authors declare that they have no conflict of interest.

Open Access This article is licensed under a Creative Commons Attribution 4.0 International License, which permits use, sharing, adaptation, distribution and reproduction in any medium or format, as long as you give appropriate credit to the original author(s) and the source, provide a link to the Creative Commons licence, and indicate if changes were made. The images or other third party material in this article are included in the article's Creative Commons licence, unless indicated otherwise in a credit line to the material. If material is not included in the article's Creative Commons licence and your intended use is not permitted by statutory regulation or exceeds the permitted use, you will need to obtain permission directly from the copyright holder. To view a copy of this licence, visit http://creativecommons.org/licenses/by/4.0/.

\section{References}

Agawin, N. S., S. Rabouille, M. J. Veldhuis, L. Servatius, S. Hol, H. M. van Overzee \& J. Huisman, 2007. Competition and facilitation between unicellular nitrogen-fixing cyanobacteria and non-nitrogen-fixing phytoplankton species. Limnology and Oceanography 52(5): 2233-2248.

Almuhtaram, H., A. Zamyadi \& R. Hofmann, 2021. Machine learning for anomaly detection in cyanobacterial fluorescence signals. Water Research 197: 117073.

Amorim, C. A., Ê. W. Dantas \& A. Moura, 2020. Modeling cyanobacterial blooms in tropical reservoirs: the role of physicochemical variables and trophic interactions. Science of the Total Environment 744: 140659.

Amorim, C. A. \& A. Moura, 2021. Ecological impacts of freshwater algal blooms on water quality, plankton biodiversity, structure, and ecosystem functioning. Science of the Total Environment 758: 143605.

Andersson, A., H. Höglander, C. Karlsson \& S. Huseby, 2015. Key role of phosphorus and nitrogen in regulating cyanobacterial community composition in the northern Baltic Sea. Estuarine, Coastal and Shelf Science 164: 161-171.

Antenucci, J. P., A. Ghadouani, M. A. Burford \& J. R. Romero, 2005. The long-term effect of artificial destratification on phytoplankton species composition in a subtropical reservoir. Freshwater Biology 50(6): 1081-1093.

Baek, S.-S., J. Pyo, Y. Pachepsky, Y. Park, M. Ligaray, C.-Y. Ahn, K. Hwa Cho, et al., 2020. Identification and enumeration of cyanobacteria species using a deep neural network. Ecological Indicators 115: 106395.

Beisel, J.-N., S. Thomas, P. Usseglio-Polatera \& J.-C. Moreteau, 1996. Assessing changes in community structure by dominance indices: a comparative analysis. Journal of Freshwater Ecology 11(3): 291-299.

Bertone, E., M. A. Burford \& D. P. Hamilton, 2018. Fluorescence probes for real-time remote cyanobacteria monitoring: a review of challenges and opportunities. Water Research 141: 152-162.

Bertone, E., A. Chuang, M. A. Burford \& D. P. Hamilton, 2019. In-situ fluorescence monitoring of cyanobacteria: laboratory-based quantification of species-specific measurement accuracy. Harmful Algae 87: 101625.

Blomqvist, P., A. Pettersson \& P. Hyenstrand, 1994. Ammonium-nitrogen-A key regulatory factor causing dominance of non-nitrogen-fixing cyanobacteria in aquatic systems. Archiv Fur Hydrobiologie 132(2): 141-164. 
Bockwoldt, K. A., E. R. Nodine, T. B. Mihuc, A. D. Shambaugh \& J. D. Stockwell, 2017. Reduced phytoplankton and zooplankton diversity associated with increased cyanobacteria in lake Champlain, USA. Journal of Contemporary Water Research \& Education 160(1): 100-118.

Borics, G., I. Grigorszky, S. Szabó \& J. Padisák, 2000. Phytoplankton associations in a small hypertrophic fishpond in East Hungary during a change from bottom-up to top-down control. In Reynolds, C. S., M. Dokulil \& J. Padisák (eds), The Trophic Spectrum Revisited Springer, New York: 79-90.

Bormans, M., P. W. Ford \& L. Fabbro, 2005. Spatial and temporal variability in cyanobacterial populations controlled by physical processes. Journal of Plankton Research 27(1): $61-70$.

Brasil, J., J. L. Attayde, F. R. Vasconcelos, D. D. Dantas \& V. L. Huszar, 2016. Drought-induced water-level reduction favors cyanobacteria blooms in tropical shallow lakes. Hydrobiologia 770(1): 145-164.

Bryant, D. A., 2006. The Molecular Biology of Cyanobacteria, Springer, New York:

Callieri, C. \& J. Stockner, 2000. Picocyanobacteria success in oligotrophic lakes: fact or fiction? Journal of Limnology 59(1): 72-76.

Carey, C. C., B. W. Ibelings, E. P. Hoffmann, D. P. Hamilton \& J. D. Brookes, 2012. Eco-physiological adaptations that favour freshwater cyanobacteria in a changing climate. Water Research 46(5): 1394-1407.

Carvalho, L., C. McDonald, C. de Hoyos, U. Mischke, G. Phillips, G. Borics \& J. Van Wichelen, 2013. Sustaining recreational quality of European lakes: minimizing the health risks from algal blooms through phosphorus control. Journal of Applied Ecology 50(2): 315-323.

Catherine, Q., W. Susanna, E.-S. Isidora, H. Mark, V. Aurelie \& H. Jean-François, 2013. A review of current knowledge on toxic benthic freshwater cyanobacteria-ecology, toxin production and risk management. Water Research 47(15): 5464-5479.

Chellappa, N. T. \& M. A. M. Costa, 2003. Dominant and coexisting species of Cyanobacteria from a Eutrophicated reservoir of Rio Grande do Norte State, Brazil. Acta Oecologica 24: S3-S10.

Chorus, I. \& M. Welker, 2021. Toxic Cyanobacteria in Water: A Guide to Their Public Health Consequences, Monitoring and Management, Taylor \& Francis, Routledge:

Cloern, J. E., 2018. Why large cells dominate estuarine phytoplankton. Limnology and Oceanography 63(S1): S392S409.

D’Agostino, P. M., J. N. Woodhouse, A. K. Makower, A. C. Yeung, S. E. Ongley, M. L. Micallef \& B. A. Neilan, 2016. Advances in genomics, transcriptomics and proteomics of toxin-producing cyanobacteria. Environmental Microbiology Reports 8(1): 3-13.

Dokulil, M. T. \& J. Mayer, 1996. Population dynamics and photosynthetic rates of a Cylindrospermopsis-Limnothrix association in a highly eutrophic urban lake, Alte Donau, Vienna, Austria. Algological Studies/archiv Für Hydrobiologie 83: 179-195.

Dokulil, M. T. \& K. Teubner, 2000. Cyanobacterial dominance in lakes. Hydrobiologia 438(1): 1-12.
Ekvall, M. K., P. Urrutia-Cordero \& L.-A. Hansson, 2014. Linking cascading effects of fish predation and zooplankton grazing to reduced cyanobacterial biomass and toxin levels following biomanipulation. PLoS ONE 9(11): e112956.

Ferber, L., S. Levine, A. Lini \& G. Livingston, 2004. Do cyanobacteria dominate in eutrophic lakes because they fix atmospheric nitrogen? Freshwater Biology 49(6): 690-708.

Fernández, C., V. Estrada \& E. R. Parodi, 2015. Factors triggering cyanobacteria dominance and succession during blooms in a hypereutrophic drinking water supply reservoir. Water, Air, \& Soil Pollution 226(3): 73.

Gardner, R. C., 2000. Correlation, causation, motivation, and second language acquisition. Canadian Psychology/psychologie Canadienne 41(1): 10.

Gallego, I., P. Venail \& B. W. Ibelings, 2019. Size differences predict niche and relative fitness differences between phytoplankton species but not their coexistence. The ISME Journal 13(5): 1133-1143.

Ger, K. A., L. A. Hansson \& M. Lürling, 2014. Understanding cyanobacteria-zooplankton interactions in a more eutrophic world. Freshwater Biology 59(9): 1783-1798.

Hamilton, D. P., N. Salmaso \& H. W. Paerl, 2016. Mitigating harmful cyanobacterial blooms: strategies for control of nitrogen and phosphorus loads. Aquatic Ecology 50(3): 351-366.

Hauke, J. \& T. Kossowski, 2011. Comparison of values of Pearson's and Spearman's correlation coefficients on the same sets of data. Quaestiones Geographicae 30(2): 87-93.

Havlik, I., P. Lindner, T. Scheper \& K. F. Reardon, 2013. Online monitoring of large cultivations of microalgae and cyanobacteria. Trends in Biotechnology 31(7): 406-414.

Hawkins, P. R., J. Holliday, A. Kathuria \& L. Bowling, 2005. Change in cyanobacterial biovolume due to preservation by Lugol's Iodine. Harmful Algae 4(6): 1033-1043.

Hillebrand, H., C. D. Dürselen, D. Kirschtel, U. Pollingher \& T. Zohary, 1999. Biovolume calculation for pelagic and benthic microalgae. Journal of Phycology 35(2): 403-424.

Imai, H., K.-H. Chang, M. Kusaba \& S.-I. Nakano, 2009. Temperature-dependent dominance of Microcystis (Cyanophyceae) species: $M$. aeruginosa and $M$. wesenbergii. Journal of Plankton Research 31(2): 171-178.

Jasser, I. \& C. Callieri, 2017. Picocyanobacteria: the smallest cell-size cyanobacteria. In Meriluoto, J., L. Spoof \& G. A. Codd (eds), Handbook on Cyanobacterial Monitoring and Cyanotoxin Analysis Wiley, Chichester: 19-27.

Jiang, Y., P. Xiao, Y. Liu, J. Wang \& R. Li, 2017. Targeted deep sequencing reveals high diversity and variable dominance of bloom-forming cyanobacteria in eutrophic lakes. Harmful Algae 64: 42-50.

Jing, L., C. Wu, J. Liu, H. Wang \& H. Ao, 2013. The effects of dredging on nitrogen balance in sediment-water microcosms and implications to dredging projects. Ecological Engineering 52: 167-174.

Lampert, W., 1987. Laboratory studies on zooplanktoncyanobacteria interactions. New Zealand Journal of Marine and Freshwater Research 21(3): 483-490.

Lewis, D. M., J. A. Elliott, M. F. Lambert \& C. S. Reynolds, 2002. The simulation of an Australian reservoir using a 
phytoplankton community model: protech. Ecological Modelling 150(1): 107-116.

Li, H., M. Barber, J. Lu \& R. Goel, 2020. Microbial community successions and their dynamic functions during harmful cyanobacterial blooms in a freshwater lake. Water Research 185: 116292.

Liu, H., Z. C. Zheng, B. Young \& T. D. Harris, 2019. Threedimensional numerical modeling of the cyanobacterium Microcystis transport and its population dynamics in a large freshwater reservoir. Ecological Modelling 398: 20-34.

Lucius, M. A., K. E. Johnston, L. W. Eichler, J. L. Farrell, V. W. Moriarty \& R. A. Relyea, 2020. Using machine learning to correct for nonphotochemical quenching in high-frequency, in vivo fluorometer data. Limnology and Oceanography: Methods 18(9): 477-494.

Ludwig, J. A., L. Quartet, J. F. Reynolds \& J. Reynolds, 1988. Statistical Ecology: A Primer in Methods and Computing, Wiley, Chichester:

Lürling, M., F. Eshetu, E. J. Faassen, S. Kosten \& V. L. Huszar, 2013. Comparison of cyanobacterial and green algal growth rates at different temperatures. Freshwater Biology 58(3): 552-559.

Lürling, M., D. Meng \& E. J. Faassen, 2014. Effects of hydrogen peroxide and ultrasound on biomass reduction and toxin release in the cyanobacterium Microcystis aeruginosa. Toxins 6(12): 3260-3280.

Kassambara, A., \& F. Mundt, 2020. factoextra: Extract and visualize the results of multivariate data analyses. R package version 1.0.7. https://CRAN.R-project.org/ package $=$ factoextra

Matthijs, H. C., P. M. Visser, B. Reeze, J. Meeuse, P. C. Slot, G. Wijn \& J. Huisman, 2012. Selective suppression of harmful cyanobacteria in an entire lake with hydrogen peroxide. Water Research 46(5): 1460-1472.

McGregor, G. B. \& L. D. Fabbro, 2000. Dominance of Cylindrospermopsis raciborskii (Nostocales, Cyanoprokaryota) in Queensland tropical and subtropical reservoirs: implications for monitoring and management. Lakes \& Reservoirs: Research \& Management 5(3): 195-205.

McNaughton, S., 1967. Relationships among functional properties of Californian grassland. Nature 216(5111): 168-169.

Metcalf, J. S. \& G. A. Codd, 2012. Cyanotoxins. In Whitton, B. A. (ed), Ecology of Cyanobacteria II: Their Diversity in Space and Time Springer, Dordrecht: 651-675.

Moreira, C., V. Ramos, J. Azevedo \& V. Vasconcelos, 2014. Methods to detect cyanobacteria and their toxins in the environment. Applied Microbiology and Biotechnology 98(19): 8073-8082.

Mur, L., H. Schreurs, \& P. Visser, 1993. How to control undesirable cyanobacterial dominance. Paper presented at the Proceedings of the 5th international conference on the conservation and management of lakes, Stresa, Italy.

Niamien-Ebrottie, J., S. Bhattacharyya, P. Deep \& B. Nayak, 2015. Cyanobacteria and cyanotoxins in the World. Ijar 1(8): 563-569.

Padisak, J., 1997. Cylindrospermopsis raciborskii (Woloszynska) Seenayya et Subba Raju, an expanding, highly adaptive cyanobacterium: worldwide distribution and review of its ecology. Archiv Für Hydrobiologie Supplementband Monographische Beitrage 107(4): 563-593.

Paerl, H. W. \& J. Huisman, 2009. Climate change: a catalyst for global expansion of harmful cyanobacterial blooms. Environmental Microbiology Reports 1(1): 27-37.

Pazouki, P., M. Prévost, N. McQuaid, B. Barbeau, M.-L. de Boutray, A. Zamyadi \& S. Dorner, 2016. Breakthrough of cyanobacteria in bank filtration. Water Research 102: 170-179.

Pedraza, A., G. Bueno, O. Deniz, G. Cristóbal, S. Blanco \& M. Borrego-Ramos, 2017. Automated diatom classification (Part B): a deep learning approach. Applied Sciences 7(5): 460.

Peretyatko, A., S. Teissier, S. De Backer \& L. Triest, 2012. Biomanipulation of hypereutrophic ponds: when it works and why it fails. Environmental Monitoring and Assessment 184(3): 1517-1531.

Pfeifer, F., 2012. Distribution, formation and regulation of gas vesicles. Nature Reviews Microbiology 10(10): 705-715.

Pomati, F., N. J. B. Kraft, T. Posch, B. Eugster, J. Jokela \& B. W. Ibelings, 2013. Individual cell based traits obtained by scanning flow-cytometry show selection by biotic and abiotic environmental factors during a phytoplankton spring bloom. PLoS ONE 8(8): e71677.

Présing, M., S. Herodek, L. Vörös \& I. Kóbor, 1996. Nitrogen fixation, ammonium and nitrate uptake during a bloom of Cylindrospermopsis raciborskii in Lake Balaton. Archiv Fur Hydrobiologie 136(4): 553-562.

R Core Team, 2020. R: A language and environment for statistical computing. R Foundation for Statistical Computing, Vienna, Austria. https://www.R-project.org/.

Reynolds, C. \& A. Irish, 1997. Modelling phytoplankton dynamics in lakes and reservoirs: the problem of in-situ growth rates. Hydrobiologia 349(1): 5-17.

Reynolds, C. S., V. Huszar, C. Kruk, L. Naselli-Flores \& S. Melo, 2002. Towards a functional classification of the freshwater phytoplankton. Journal of Plankton Research 24(5): 417-428.

Rigosi, A., C. C. Carey, B. W. Ibelings \& J. D. Brookes, 2014. The interaction between climate warming and eutrophication to promote cyanobacteria is dependent on trophic state and varies among taxa. Limnology and Oceanography 59(1): 99-114.

Rigosi, A., P. Hanson, D. P. Hamilton, M. Hipsey, J. A. Rusak, J. Bois \& B. Qin, 2015. Determining the probability of cyanobacterial blooms: the application of Bayesian networks in multiple lake systems. Ecological Applications 25(1): 186-199.

Robarts, R. D. \& T. Zohary, 1987. Temperature effects on photosynthetic capacity, respiration, and growth rates of bloom-forming cyanobacteria. New Zealand Journal of Marine and Freshwater Research 21(3): 391-399.

Rocha, M. I. A., F. Recknagel, R. T. Minoti, V. L. M. Huszar, B. Kozlowsky-Suzuki, H. Cao \& C. W. C. Branco, 2019. Assessing the effect of abiotic variables and zooplankton on picocyanobacterial dominance in two tropical mesotrophic reservoirs by means of evolutionary computation. Water Research 149: 120-129.

Rouco, M., V. López-Rodas, R. González, I. E. Huertas, M. J. García-Sánchez, A. Flores-Moya \& E. Costas, 2014. The 
limit of the genetic adaptation to copper in freshwater phytoplankton. Oecologia 175(4): 1179-1188.

Rousso, B. Z., E. Bertone, R. Stewart \& D. P. Hamilton, 2020. A systematic literature review of forecasting and predictive models for cyanobacteria blooms in freshwater lakes. Water Research 182: 115959.

Rousso, B. Z., E. Bertone, R. A. Stewart, K. Rinke \& D. P. Hamilton, 2021. Light-induced fluorescence quenching leads to errors in sensor measurements of phytoplankton chlorophyll and phycocyanin. Water Research 198: 117133.

Rousso, B. Z., Bertone, E., Stewart, R. A., Aguiar A., Chuang, A., Hamilton, D. P., \& Burford, M. Chlorophyll and phycocyanin in-situ fluorescence in mixed cyanobacterial species assemblages: Effects of morphology, cell size and growth phase. Water Research (under review)

Shurin, J. B., J. E. Havel, M. A. Leibold \& B. Pinel-Alloul, 2000. Local and regional zooplankton species richness: a scaleindependent test for saturation. Ecology 81(11): 3062-3073.

Simis, S. G. H., A. Ruiz-Verdú, J. A. Domínguez-Gómez, R. Peña-Martinez, S. W. M. Peters \& H. J. Gons, 2007. Influence of phytoplankton pigment composition on remote sensing of cyanobacterial biomass. Remote Sensing of Environment 106(4): 414-427.

Song, H., J. Xu, M. Lavoie, X. Fan, G. Liu, L. Sun \& H. Qian, 2017. Biological and chemical factors driving the temporal distribution of cyanobacteria and heterotrophic bacteria in a eutrophic lake (West Lake, China). Applied Microbiology and Biotechnology 101(4): 1685-1696.

Spellerberg, I. F. \& P. J. Fedor, 2003. A tribute to Claude Shannon (1916-2001) and a plea for more rigorous use of species richness, species diversity and the 'ShannonWiener' Index. Global Ecology and Biogeography 12(3): 177-179.

Sukenik, A., A. Quesada \& N. Salmaso, 2015. Global expansion of toxic and non-toxic cyanobacteria: effect on ecosystem functioning. Biodiversity and Conservation 24(4): 889-908.

Thomas, M. K., S. Fontana, M. Reyes \& F. Pomati, 2018. Quantifying cell densities and biovolumes of phytoplankton communities and functional groups using scanning flow cytometry, machine learning and unsupervised clustering. PLoS ONE 13(5): e0196225.

Tromas, N., N. Fortin, L. Bedrani, Y. Terrat, P. Cardoso, D. Bird \& B. J. Shapiro, 2017. Characterising and predicting cyanobacterial blooms in an 8-year amplicon sequencing time course. The ISME Journal 11(8): 1746-1763.

Urrutia-Cordero, P., M. K. Ekvall \& L.-A. Hansson, 2016. Controlling harmful cyanobacteria: taxa-specific responses of cyanobacteria to grazing by large-bodied Daphnia in a biomanipulation scenario. PLoS ONE 11(4): e0153032.

Urrutia-Cordero, P., M. K. Ekvall \& L. A. Hansson, 2015. Responses of cyanobacteria to herbivorous zooplankton across predator regimes: who mows the bloom? Freshwater Biology 60(5): 960-972.

Vanderley, R. F., K. A. Ger, V. Becker, M. G. T. A. Bezerra \& R. Panosso, 2021. Abiotic factors driving cyanobacterial biomass and composition under perennial bloom conditions in tropical latitudes. Hydrobiologia 848(4): 943-960.
Vanderploeg, H. A., J. R. Liebig, W. W. Carmichael, M. A. Agy, T. H. Johengen, G. L. Fahnenstiel \& T. F. Nalepa, 2001. Zebra mussel (Dreissena polymorpha) selective filtration promoted toxic Microcystis blooms in Saginaw Bay (Lake Huron) and Lake Erie. Canadian Journal of Fisheries and Aquatic Sciences 58(6): 1208-1221.

Visser, P. M., B. W. Ibelings, M. Bormans \& J. Huisman, 2016. Artificial mixing to control cyanobacterial blooms: a review. Aquatic Ecology 50(3): 423-441.

Wan, L., X. Chen, Q. Deng, L. Yang, X. Li, J. Zhang \& X. Cao, 2019. Phosphorus strategy in bloom-forming cyanobacteria (Dolichospermum and Microcystis) and its role in their succession. Harmful Algae 84: 46-55.

Watson, S. B., P. Monis, P. Baker \& S. Giglio, 2016. Biochemistry and genetics of taste- and odor-producing cyanobacteria. Harmful Algae 54: 112-127.

Wehr, J. D., 1989. Experimental tests of nutrient limitation in freshwater picoplankton. Applied and Environmental Microbiology 55(6): 1605-1611.

Wei, T., \& V. Simko, 2017. R package "corrplot": Visualization of a Correlation Matrix (Version 0.84). https://github.com/ taiyun/corrplot

Whitton, B. A. \& M. Potts, 2007. The Ecology of Cyanobacteria: Their Diversity in Time and Space, Springer, New York:

Willén, E., 2000. Phytoplankton in water quality assessment-an indicator concept. Hydrological and Limnological Aspects of Lake Monitoring 2: 58-80.

Winslow, L., J. Read, R. Woolway, J. Brentrup, T. Leach, J. Zwart, S. Albers, \& D. Collinge, 2019. rLakeAnalyzer: Lake Physics Tools. R package version 1.11.4.1. https:// CRAN.R-project.org/package=rLakeAnalyzer

Xiao, M., M. Li \& C. S. Reynolds, 2018. Colony formation in the cyanobacterium Microcystis. Biological Reviews 93(3): 1399-1420.

Yang, J., H. Lv, J. Yang, L. Liu, X. Yu \& H. Chen, 2016. Decline in water level boosts cyanobacteria dominance in subtropical reservoirs. Science of the Total Environment 557-558: 445-452.

Ye, L., C.-W. Chang, S.-I.S. Matsuzaki, N. Takamura, C. E. Widdicombe \& C.-H. Hsieh, 2019. Functional diversity promotes phytoplankton resource use efficiency. Journal of Ecology 107(5): 2353-2363.

Yoshikawa, T. \& K. Furuya, 2006. Effects of diurnal variations in phytoplankton photosynthesis obtained from natural fluorescence. Marine Biology 150(2): 299-311.

Zamyadi, A., S. Dorner, S. Sauvé, D. Ellis, A. Bolduc, C. Bastien \& M. Prévost, 2013. Species-dependence of cyanobacteria removal efficiency by different drinking water treatment processes. Water Research 47(8): 2689-2700.

Zamyadi, A., C. M. Glover, A. Yasir, R. Stuetz, G. Newcombe, N. D. Crosbie, R. Henderson, et al., 2021. Toxic cyanobacteria in water supply systems: data analysis to map global challenges and demonstrate the benefits of multi-barrier treatment approaches. H2Open Journal. https://doi.org/10.2166/h2oj.2021.067.

Zhang, W. \& Y. R. Rao, 2012. Application of a eutrophication model for assessing water quality in Lake Winnipeg. Journal of Great Lakes Research 38: 158-173. 
Zhang, Z., X. Fan, W. J. G. M. Peijnenburg, M. Zhang, L. Sun, Y. Zhai \& H. Qian, 2021. Alteration of dominant cyanobacteria in different bloom periods caused by abiotic factors and species interactions. Journal of Environmental Sciences 99: 1-9.
Publisher's Note Springer Nature remains neutral with regard to jurisdictional claims in published maps and institutional affiliations. 